\title{
O Contestado nos currículos escolares: a valorização da história regional
}

\section{Resumo}

Este trabalho se propõe analisar, a partir do movimento social do Contestado, a importância da valorização nos currículos escolares da História Regional. Cabe ressaltar que os currículos da educação básica encontram-se inseridos num contexto de disputa, espaço em que se privilegiam determinadas opções sobre seus componentes enquanto ato político. Este trabalho se propõe analisar o espaço dedicado ao tema do Contestado e às concepções epistemológicas reinantes a respeito do mesmo nos currículos de história do ensino fundamental e médio no Estado de Santa Catarina. Destaca-se a falta de contextualização dos conteúdos do currículo escolar distante da realidade, bem como o isolamento e a fragmentação das disciplinas. As instituições de ensino produzem distorções do mundo produtivo. É importante salientar que estas distorções acontecem na escola sob influência da sociedade; por outro lado, se concretizam na sociedade sob influência da escola. Nesta pesquisa, com o intuito de analisar o espaço ocupado pelo Contestado e pela História Regional, foram entrevistados três Professores, que exercem suas atividades profissionais na rede pública Estadual em Curitibanos. Através das entrevistas observou-se que o movimento social do Contestado e seus desdobramentos na atual situação educacional da região constituem tema de grande amplitude. No momento em que se buscam elementos explicativos para as interrogações sobre o que faz com que hoje sejamos o que realmente somos, torna-se indispensável recorrer às instituições encarregadas da educação formal na sociedade. Ao mesmo tempo em que influem na determinação dos aspectos sociais, políticos e econômicos, estas instituições sofrem determinações, o que vem restringir espaço de valorização da história regional nos currículos escolares do Estado de Santa Catarina.

Palavras-chave: Contestado. Currículos escolares. História Regional. Santa Catarina.

\section{Geraldo Antônio da Rosa}

Doutor em Teologia: Religião e Educação. docente do Programa de Mestrado em Educação - PPGE, na Universidade do Planalto

Catarinense - UNIPLAC, em Lages - SC. geraldorosa06@gmail.com

\section{Para citar este artigo:}

ROSA, Geraldo Antonia da. O contestado nos currículos escolares: a valorização da história regional . Revista PerCursos. Florianópolis, v. 14, n.26, jan./jun. 2013. p. 158 - 186.

DOI: $10.5965 / 1984724214262013158$

http://dx.doi.org/10.5965/1984724614262013158 


\title{
The Contestado in school curriculum: the valorization of the regional history
}

\begin{abstract}
This work proposes to analyse, from the Contestado Social Movement, the importance of the valorization in the scholar curriculum of the Regional History. The Contestado Social Movement, that which has the name of Contestado War, was the one of the greatest conflicts of Brazil. This work proposes to analyse the space dedicated to the theme of the Contestado and to the epistemological conceptions which reign in point of that in the curriculum of the basic and intermediate teaching in the State of Santa Catarina. It emphasizes the missing of contextualization of the contents of the scholar curriculum far away from the reality, as well as, the isolation and the fragmentation of the subjects. The teaching establishment produces distortions about the productive world. It's important to point out those distortions happen in the school under the influence of the society, in the other hand, they render in the society under the influence of the school. In this research, with the aim of analysing the space occupied by the Contestado and Regional History, three teachers were interviewed, who practice their professional activities in the public state net in Curitibanos. Through the interviews it could be observed that the Contestado Social Movement and its display in the actual educational situation in the region involves a theme of great amplitude. In the moment when are searched informative elements to the questions about what does wherewith we are what we really are today, it's become indispensable to run over to the institutions which are put in charge about the informal educations in the society. In the same time that it influences to the determination of the social, political and economic aspects, those institutions suffer determinations, which come to limit the space of the valorization of the regional history in the scholar curriculums of the State of Santa Catarina.
\end{abstract}

Keywords: Contestado, Scholar Curriculums. History of Education. Santa Catarina. 


\section{Introdução}

Ao analisarmos os currículos escolares da educação básica nos defrontamos com lacunas no que se refere à incorporação da História Regional. Este artigo busca, precisamente, analisar o movimento social do Contestado nos currículos escolares, enquanto reflexão sobre a valorização da História Regional. Partindo do pressuposto da inexistência de neutralidade na educação, podemos constatar que concepção ou que concepções estão sendo assumidas no processo de educação deste povo. A respeito desta questão Sacristán e Gómez (1998, p. 124) advertem:

Os problemas básicos que o tratamento de currículo agrupa, dependem da orientação de que seja objeto, mas poderíamos resumi-los em torno das seguintes questões:

- O que ensinar, ou que valores, atitudes e conhecimentos estão implicados nos objetivos?

- Quem está autorizado a participar nas decisões do conteúdo da escolaridade?

- Por que ensinar o que se ensina, deixando de lado muitas outras coisas? Trata-se da justificativa do conteúdo.

- Todos esses objetivos devem ser para todos os alunos ou somente para alguns deles?

- Quem tem melhor acesso às formas legítimas do conhecimento?

- Esses conhecimentos servem a quais interesses?

- Que processos incidem e transformam as decisões tomadas até se tornarem prática real?

Com base nestas interrogações procurar-se-á analisar os currículos no decorrer da história educacional, longe da sua neutralidade, o que seria uma ilusão ou disfarce, uma vez que a educação é por excelência um ato político. Esses currículos contêm de forma palpável os interesses dos grupos dominantes que impuseram a partir de suas aspirações todo o processo de educação de um povo. Embora nem sempre os educadores, como a sociedade em geral, tenham tido clareza quanto às políticas que permearam os currículos escolares. Apple (1989, p. 15), em sua análise voltada à perspectiva contemporânea do Currículo, observa: 
[...] O trabalho do magistério tem sofrido mudanças substanciais. Um complexo processo de desqualificação e requalificação está ocorrendo, um processo no qual grande parte do magistério está perdendo controle de partes substanciais do currículo e da pedagogia, à medida que as ideologias e práticas capitalistas penetram no centro de um grande número de salas de aulas.

A partir desta constatação, percebe-se a que interesses as escolas se encontram submetidas, bem como o processo de fragmentação do trabalho docente. Este esfacelamento do processo formal de educação empobrece o ato de educar, o fazer pedagógico, uma vez que, ao se criarem especializações e matrizes curriculares fragmentadas, o docente deixa de ser aquele que concebe, o arquiteto, o artífice, para se tornar um mero executor das políticas emanadas burocraticamente de cima para baixo, servindo aos interesses dos que dominam.

Partindo do pressuposto de que a educação deve ir ao encontro dos legítimos interesses da sociedade e não dos estereótipos ditados de forma escancarada, autoritária e até simbolicamente violenta pelas minorias dominadoras, existe no processo de educação de um povo o currículo assumido pelas instituições educacionais, que de certa forma se encontra atrelado às políticas educacionais vigentes. Os currículos educacionais nem sempre são implementados de forma aberta e clara nas instituições e no seio da própria sociedade. É importante se destacar que os currículos assumem um caráter de grande importância na educação de um povo. Numa concepção de educação libertadora, uma instituição que orienta seus projetos educativos a partir da ótica do capital trai os verdadeiros ideais educacionais, mormente o continente latino-americano cuja estrutura social gera múltiplos processos de exclusão.

Numa reflexão crítica acerca da esfera educacional, Apple (1989, p. 27) faz a seguinte advertência:

(...) Precisamos ter cuidado quanto a esses efeitos. A minha própria análise me leva, portanto, a estas duas cautelas: dar-se conta de que entender as escolas e atuar nelas não é o suficiente, mas também saber isto e ignorá-las é simplesmente errado. Como tentarei demonstrar, na verdade, o sistema educacional - exatamente por sua localização no interior de uma trama mais ampla das relações sociais - pode constituir 
um importante terreno no qual ações significativas podem ser desenvolvidas.

Com efeito, pode-se constatar que grande parte dos "educadores" trabalham na perspectiva de serem simples executores de políticas emanadas dos grupos dominantes. É importante destacar a necessidade de se refletir sobre as influências dos sistemas produtivos nos currículos e a fragmentação dos processos produtivos. Esta realidade se fez e se faz presente na história do Brasil, e a região do Contestado, inserida neste contexto, carrega estes elementos dentro da sua realidade educacional.

Sabe-se que o estudo concernente às teorias do currículo é recente, de modo peculiar no Brasil, onde o sistema de ensino foi montado de forma autoritária. Porém torna-se importante assinalar que as preocupações relativas ao currículo e ao que ele produz aparecem junto com a Pedagogia crítica na década de 1980. Este período é marcado pelo fim da Guerra Fria, período em que a hegemonia referencial funcionalista norte-americana foi abalada. Destaca-se, neste contexto, o surgimento dos movimentos pedagógicos em torno da globalização e interdisciplinaridade, buscando o resgate do conhecimento globalizado.

Santomé (1998, p.10) faz o seguinte destaque:

O movimento pedagógico a favor da globalização e da interdisciplinaridade nasceu de reivindicações progressistas de grupos ideológicos e políticos que lutavam por uma maior democratização da sociedade. Podemos constatar que ocorre uma coincidência temporal, por exemplo, entre os ataques que os movimentos sindicais do inicio do século dirigem contra as políticas trabalhistas e de produção planejadas sob os pressupostos de 'um controle cientifico' segundo os princípios daquilo que Frederick Winslow Taylor rotulou de 'Management científico', por outro lado, com os discursos de John Dewey e William H. Hilpatrick, exigindo uma reconsideração completa, tanto da função como da prática de educação.

O autor faz uma análise dos movimentos em prol da democratização da sociedade fazendo um contraponto com o sistema produtivo do mundo medieval. Observa-se, por exemplo, que nas oficinas na Idade Medieval o domínio do conhecimento acontecia de forma integral, ou seja, o trabalhador dominava todo o processo produtivo. Com o advento do capitalismo e da Revolução Industrial, que veio consolidar este sistema nos 
finais do século XIX e início do século $X X$, houve uma autêntica revolução no funcionamento dos sistemas de produção e distribuição no âmbito empresarial, revolução voltada para a acumulação do capital e o barateamento da mão-de-obra. Para que tal intento se concretizasse, seriam estratégicas a desapropriação do conhecimento e a consequente desqualificação do trabalhador, impedindo-lhe de participar nas decisões do processo produtivo, acentuando a divisão técnica do trabalho e a consequente fragmentação do processo produtivo. Esse processo de desqualificação oriundo da divisão "científica" do trabalho faz-se presente de maneira diferente em diferentes espaços. Na região do Contestado, em que predominou uma economia de exploração da madeira e das grandes fazendas, criou-se uma classe de trabalhadores subservientes aos atuais interesses, não havendo, por parte das autoridades e do sistema econômico, preocupação com uma mão-de-obra qualificada, estabelecendo-se fortes diferenças entre o trabalho manual e intelectual.

Este processo de fragmentação ocorrido no sistema produtivo passou a fazer parte dos sistemas educacionais. É mister ressaltar, então, a relação entre sistema educacional e currículo escolar. Professores e estudantes foram alijados do processo decisório e de crítica à realidade. O currículo oculto nas salas de aula passou a privilegiar as habilidades relativas à obediência e à subserviência às autoridades. Santomé (1998, p.14) faz o seguinte esclarecimento:

Este processo de 'despersonalização' e de preparação da juventude para incorporar-se e assumir as regras do jogo de um modelo de sociedade, de produção e relações de trabalho no qual se pretende que a maioria das pessoas não possa intervir e decidir, é contestado não só pelos movimentos sindicais e partidos progressistas, mas também pela própria classe docente e estudantil.

Destaca-se a falta de contextualização dos conteúdos do currículo escolar distante da realidade, bem como o isolamento e a fragmentação das disciplinas. As instituições de ensino produzem distorções do mundo produtivo. É importante salientar que estas distorções acontecem na escola sob influência da sociedade; por outro lado, se concretizam na sociedade sob influência da escola. 
A partir das reflexões acerca dos sistemas produtivos, compete lançar os seguintes questionamentos:

- O que é educação?

- A quem serve a escola?

- Que conteúdos fazem parte do currículo escolar?

- Em nome de que, e de quem?

Diante das consequências socialmente negativas das políticas neoliberais e do processo de globalização econômica, urge repensar as estruturas institucionais no continente, bem como trazer para um efetivo debate as estruturas existentes e os mecanismos que as proporcionaram.

Em nosso país, observam-se poucos avanços no setor educacional, ao contrário do que ocorreu com a privatização do patrimônio público, a concentração de renda e o aumento do processo de exclusão. Diante desta realidade, Santomé conclui:

Poucas vezes ao longo da história foi tão urgente a aposta em uma educação verdadeiramente comprometida com valores de democracia, solidariedade e crítica, se quisermos ajudar cidadãos e cidadãs a enfrentar essas políticas de flexibilidade, descentralização e autonomia propugnadas nas esferas trabalhistas. É preciso formas pessoas com capacidade crítica e solidariedade, se não quisermos deixá-las mais indefesas. (SANTOMÉ, 1998, p. 23)

Muitas práticas das escolas prendem-se ao fato de as mesmas estarem vinculadas e submissas aos interesses dos grupos dominantes. Quanto mais centralizados forem os mecanismos de poder, tanto mais se prioriza a obediência, não dentro dos pressupostos da verdadeira educação, porém na ótica de uma pedagogia enganosa. Dentro desta pseudopedagogia são utilizadas as estratégias intimidativas, a manipulação e outras táticas planejadas e apresentadas aos indivíduos como lei, como dogma. A respeito desta questão, Castells et al. observam: "Assim, a obediência chega a ser um instrumento chave para a reprodução da cultura dominante, entendendo que os pensamentos independentes e as ações estão regidos pelo sistema e/ou reprimidos pelo indivíduo que 
tem submetido seu desejo à armadilha da pedagogia enganosa." (CASTELS et al., 1996, p. 89)

Trabalhando numa perspectiva emancipatória, percebe-se nas regiões onde o capital se estruturou de maneira extremamente selvagem, com práticas políticas coronelistas, nepotistas e paternalistas, que este sistema gerou uma certa apatia na população. Quanto aos currículos, as questões que se encontram inseridas no contexto sociocultural são trabalhadas a partir dos interesses dominantes, levando os cidadãos a aceitarem-nos ou agirem passivamente.

Torna-se imperioso que a educação responda aos reais anseios da coletividade. Hoje o mundo clama por democracia, ou seja, percebe-se um anseio de que exista uma maior abertura aos processos participativos. A sociedade tal qual se encontra apresentase voltada aos interesses minoritários dos dominadores. Henry Giroux faz a seguinte sugestão:

Primeiro, a noção de diferença deve ser vista em termos educacionais mais amplos que aprofundem a possibilidade de se reconstruir a democracia e as esferas públicas democráticas. Isso significa, organizar as escolas e a pedagogia em torno de um sentido de propósito e significado que se torne a diferença fundamental para uma noção crítica de cidadania e vida pública democrática. (GIROUX, 1999, p. 205)

Não existe interesse, da parte de quem domina, na projeção de avanços sociais. Por isso, os conhecimentos, o currículo, a ciência passam pelo crivo da oficialidade. Um dos questionamentos a se fazer é que saberes devem ser construídos nos currículos.

\section{Currículo oculto e as realções de poder}

Karl Marx (1986), em sua análise do sistema capitalista na obra Ideologia alemã, vê a mercadoria como sendo de fundamental importância para o sistema capitalista de exploração. A mercadoria é lançada no mercado de forma fria, como simples objeto a ser comercializado. Porém, como pano de fundo deste sistema, ocultam-se signos das relações sociais que a produziram dentro de um conjunto de histórias. 
A escola reflete a sociedade servindo como espelho, principalmente no que se refere aos elementos constitutivos do currículo oculto. Michael W. Apple (1989, p. 83) analisa este mecanismo estabelecendo a seguinte reflexão:

A 'sociedade' precisa de trabalhadores dóceis; as escolas através de suas relações sociais e de seu currículo oculto, garantem de alguma forma esta produção de docilidade. Trabalhadores obedientes no mercado de trabalho são espelhados no 'mercado de idéias' da escola.

Esta teoria parte do pressuposto de que a economia exige dos trabalhadores, no seu cotidiano, determinados traços comportamentais e habilidades. As necessidades econômicas são absorvidas em outros setores da sociedade e a instituição educacional as incorpora cotidianamente em seu currículo.

Contra esse esquema estrutural pode constar-se a ação de parte dos trabalhadores, que partem para uma resistência aberta e organizada. Para que isto aconteça, necessário se faz o rompimento com a lógica imposta pelo processo de dominação capitalista. Ademais, em nível de currículo escolar devem-se superar as formas dominantes da produção cultural. Porém, para identificar que o currículo está inserido em relações, cabe à análise educacional a tarefa de detectá-las no sentido de uma efetiva transformação. Moreira e Silva observam:

Se existe uma noção central à teorização educacional e crítica é a de poder. É a visão de que a educação e o currículo estão profundamente implicados em relações de poder que dá à teorização educacional crítica e seu caráter fundamentalmente político. Isso não quer dizer que a conceituação daquilo que constitui o poder, no contexto de educação e do currículo, seja uma questão facilmente resolvida. (MOREIRA; SILVA, 2002, p.28)

Ao analisar a sociedade, as instituições, o poder ideológico, os movimentos sociais, é fundamental determinar o quanto existe de econômico no político e o quanto de político no econômico. As sociedades capitalistas encontram-se estruturadas em torno da propriedade privada, da economia do mercado e da livre concorrência. A sociedade de classes, que tem o Estado como avalista, encontra-se descrita desta maneira por Marx e Engels: 
A esta propriedade privada corresponde o Estado moderno, o qual comprado paulatinamente pelos proprietários privados através dos impostos, cai completamente sob o controle destes pelo sistema da dívida pública, e cuja existência como é revelado pela alta e baixa dos valores do Estado na bolsa, tornou-se completamente dependente do crédito comercial concedido pelos proprietários privados, os burgueses. (MARX; ENGLES, 1986, p. 97)

Portanto, observa-se através das políticas que a estrutura estatal não correspondente aos legítimos interesses da sociedade civil, acontecendo a privatização do poder público. Marx e Engels prosseguem fazendo a seguinte reflexão:

A burguesia, por ser já uma classe e não mais um estamento, é obrigada a organizar-se nacionalmente, e não mais localmente, a dar uma forma geral a seu interesse médio. Através da emancipação da propriedade privada em relação à comunidade, o estado adquire uma existência particular, ao lado e fora desta sociedade civil; mas este Estado não é mais do que uma forma de organização que os burgueses necessariamente adotam, tanto no interior como no exterior, para a garantia recíproca de sua propriedade e de seus interesses. (Idem)

No plano teórico e idealizado, o Estado é maquiado com a função principal de proporcionar o bem comum à coletividade. Este Estado assume inúmeras facetas no decorrer de sua evolução histórica até galgar o patamar de Estado democrático e representativo. Frente às ações do Estado na contemporaneidade, e diante das políticas neoliberais, há que se questionar a quem ele serve e que articulações nele se desenvolvem.

Fazendo parte do Estado, a educação tem um papel importante na tentativa de criar um consenso ativo. Numa perspectiva positivista, ligada às teorias dominantes, esta seria uma tarefa essencialmente neutra. Para manter a sua legitimidade, necessário se faz que o Estado integre articuladamente as diferentes concepções que compõem os grupos sociais.

\section{Currículo e educação no movimento social do contestado}

A educação de um povo deve atender aos seus anseios, às suas expectativas, permeadas por políticas ou pela ausência delas. Neste contexto, o sistema capitalista 
gera a reprodução de sua força de trabalho. Frigotto (2000, p. 30) destaca o currículo escolar permeado pelas políticas emanadas do sistema de produção capitalista:

A educação e a formação humana terão como sujeito definidor as necessidades, as demandas do processo de acumulação do capital sob as diferentes formas históricas de sociabilidade que assumir. Ou seja, reguladas e subordinadas pela esfera privada, e à sua reprodução.

O que se observa na Região do Contestado é a reprodução de uma mão-de-obra desqualificada, submissa, e "hospedeira" dos interesses e do pensamento dos coronéis. Nesta região o povo foi educado para servir e a fazê-lo de acordo com os objetivos dos grupos dominantes.

É necessário ressaltar que a formação humana e a educação estão intimamente associadas ao processo de acumulação no sistema capitalista sob suas diferentes formas, reguladas pelo privado e pelos interesses do capital na produção. Esta realidade transcende a educação formal, muito embora esteja enfocada nos currículos escolares que trazem em sua essência opções políticas. A educação social de um povo encontra-se marcada por diferentes concepções de mundo, de homem, de sociedade e de currículo. Frigotto (2000, p. 33) dá o seguinte destaque à subordinação da sociedade aos interesses capitalistas:

Esta subordinação nem sempre é de fácil dissimulação ao longo do desenvolvimento do sistema capitalista. Assim, por diferentes maneiras, o caráter contraditório das relações sociais capitalistas pode ser explicitado no âmbito das relações entre a sociedade e os processos educativos, ou deste como um processo produtivo. Isto nos indica, de um lado que o capital é prisioneiro de sua contradição, de seus limites de concepção (fragmentária) da realidade, portanto não é onisciente e, de outro, que é confrontado por interesses de classes trabalhadoras que the são antagônicos.

Analisando a educação no município de Curitibanos-SC, observa-se que o homem é fruto de uma sociedade e de um processo de colonização, em que a matriz cultural proporciona que o colonizado se identifique com o colonizador. Dentro desta perspectiva suas raízes, sua idiossincrasia, devem ser apagadas. A partir desta análise sobre o processo de educação do sertanejo, denota-se uma submissão do conquistado ao conquistador. 
Herculano Teixeira d'Assumpção (1917, p. 175) traça o seguinte perfil da população sertaneja, numa visão coronelista, classificando-a como bandidos, ingênuos, fanáticos que se transformaram em bandoleiros:

Tratando-se dos rudes costumes, aliás justificáveis, do sertão catharinense, não deprimo o seu próspero estado. As condições de incultura da população sertaneja, mergulhada como está nas trevas da ignorância, são resultado da vastidão do nosso território e da disseminação de seus habitantes.

Em uma de suas abordagens, Herculano Teixeira d'Assumpção (1917) referia que o estado de Santa Catarina, na época, ou seja, nas primeiras décadas do século XX, tinha uma escola normal e um ginásio, além de duzentas escolas primárias. O autor diz que esta estrutura educacional implantada em Santa Catarina tinha como referencial os modernos processos já implantados há alguns anos em São Paulo e em Minas Gerais.

D’Assumpção (1917) afirma ainda que, ao sair da região de colonização alemã, com uma população ordeira, disciplinada e prestativa, e dirigindo-se numa expedição a Curitibanos, constatou que na Zona Serrana só reinavam a anarquia, a miséria e a completa desorganização na vida pública e privada.

Nilson Thomé faz a seguinte abordagem histórica acerca da educação no Contestado catarinense:

O estudo da educação na história do Contestado revela-nos aqui a reprodução do fenômeno da dominação, tal como ocorria em Santa Catarina e no Planalto Serrano, fruto do coronelismo e do sistema oligárquico que predominava historicamente na região, onde alguns poucos fazendeiros ricos exerciam o mandonismo sobre a grande maioria subserviente. (Thomé, 2002, p. 62)

Após a Guerra do Contestado desenvolveu-se um novo olhar sobre as questões educativas. Pode-se ressaltar a solicitação por parte das autoridades locais de estabelecimentos de ensino voltados à educação do povo na região. Tem-se, por exemplo, o surgimento de uma escola de primeiras letras, destinada a alunos do sexo masculino. Em 1917, após a Guerra do Contestado, que durou de 1912 a 1916, o Coronel Marcos Gonçalves de Farias, que cuidara do processo de restauração da Vila, apresentou um relatório ao governador catarinense, na qualidade de superintendente local, o qual é 
analisado da seguinte maneira por Lemos (1983), no sentido que a ausência educação formal constitui na região uma das causas indiretas do movimento social do Contestado. O acesso à educação foi um privilégio dos grupos de poder, restringindo-se apenas às classes mais abastadas e relegando os sertanejos à educação informal. Em termos educacionais destaca-se a importância dos monges, que encontram espaço no mundo sertanejo para uma prática pedagógica.

A respeito desta questão Marx e Engels fazem a advertência: "Os pensamentos da classe dominante são também, em todas as épocas, os pensamentos dominantes; em outras palavras, a classe que é poder material numa determinada sociedade é também o poder espiritual dominante". (MARX; ENGELS,1986, p. 45)

Constata-se a importância dos monges João Maria de Agostini (1840), João Maria de Jesus (1893) e José Maria (1910), que tiveram, além de caráter messiânico, fundamental importância na ação educativa através da conversa informal, da pregação e da catequese que os aproximavam do sertanejo. Este trabalho servia para despertar as consciências oprimidas a lutarem pela libertação.

O currículo de educação dos monges dispensava as formalidades educacionais vigentes, uma vez que tomava como ponto de referência uma teoria aproximada à prática. O processo educacional do Contestado girava em torno de um futuro melhor. Frei Betto dá o seguinte destaque:

No âmago da dor não se conhece o futuro. Acalmada a borrasca, secadas as lágrimas, os olhos vislumbram o horizonte onde, o ciclo da vida a encarar o inverno, florescem primaveras que nos abrem a novos amores e a novas lutas. Nada mais profundo que a saudade do porvir. (Frei Betto, 2000, p. 196)

Ressalte-se que, no planalto serrano, o papel e o discurso educacional da Igreja Católica estavam voltados aos interesses dos dominadores. Sua presença pastoral pode ser classificada como quase que exclusivamente sacramental. Essa ação da Igreja Católica propiciou a abertura para o desenvolvimento de um catolicismo rústico, abrindo espaço para a emergência de lideranças carismáticas, muitas não reconhecidas pela oficialidade. Nota-se que tanto a figura dos monges como os seus ensinamentos perpetuaram-se de 
geração em geração no meio sertanejo. Observando a religiosidade popular, percebe-se que São João Maria é venerado, ainda nos dias atuais, como um grande santo, com o mesmo valor ou com maior valor do que os santos da Igreja Católica. A respeito da pedagogia presente no messianismo, Sachweh (2002, p. 89) faz a seguinte análise:

Assim como a religião não tinha necessidade de um local específico para realizar seus rituais, e as imagens dos santos acompanhavam a figura do beato e os seus seguidores, a educação não exigia a presença de um "templo" para se efetivar. Em qualquer lugar e a qualquer hora os mais velhos ensinavam os mais novos, transmitindo-lhes suas experiências e $o$ seu conhecimento empírico. Se não se pode falar em escola peregrina, pode-se perceber uma educação andarilha que acompanhava os 'irmãos' na sua peregrinação e nas suas lutas, pois foram os primeiros 'ermitões' e 'sacristãos', leigos devotos que reuniram o povo para as práticas religiosas, dirigiram o culto e tiveram responsabilidade pela guarda da capela ou ermida (local do culto). Essa forma de realizar a prática pedagógica desmistificou a escola enquanto lugar especialmente reservado para a transmissão do conhecimento das gerações mais velhas para as mais novas.

O Contestado hoje é fruto de um longo processo histórico marcado por sangue, suor e lágrimas. Admite-se que o processo educacional foi estruturado dentro da lógica da manutenção do status quo. É marcante a presença das diferentes instituições que encasteladas e comprometidas com o poder dominante agiram num longo processo opressivo que perpassa décadas.

\section{O contestado nos currículos escolares}

A Escola, hoje instituída, carrega em sua essência elementos e indicadores presentes na racionalidade do sistema capitalista. Dentre as principais ideias pode-se ressaltar a do gerenciamento científico, influência básica do industrialismo norteamericano, sinônimo da produção eficiente. A respeito desta questão Rocha dá a seguinte ênfase: “A formatação que a escola apresenta hoje é, assim, fruto do processo de assimilação da mesma lógica imanente ao capitalismo: a que procura organizar, da maneira mais racional possível, os recursos existentes". (ROCHA, 2002, p. 38) 
Essa escola sofreu fortes influências em seu currículo escolar do racionalismo e pragmatismo norte-americanos. Dentro deste contexto, foram priorizadas as disciplinas voltadas à área das ciências exatas em detrimento das ciências humanas.

As escolas públicas do Estado de Santa Catarina planejam suas atividades através da Proposta Curricular que traz em sua matriz epistemológica o materialismo dialético. Nesta concepção, o ser humano que constrói a sociedade é um ser histórico. Em seus eixos norteadores, a Proposta Curricular do Estado de Santa Catarina concebe o ser humano como sujeito que é determinado pela história ao mesmo tempo em que a constrói. Nesta perspectiva de análise dialética do processo histórico, Marx, citado na Proposta Curricular do Estado de Santa Catarina' faz a seguinte observação:

Os homens fazem sua própria história, mas não a fazem como querem: Não a fazem sob circunstâncias de sua escolha e sim sob aquelas com as quais se defrontam diretamente, legadas ou transmitidas pelo passado. A tradição das gerações mortas oprime como um pesadelo o cérebro dos vivos. (MARX apud SANTA CATARINA, 1998, p. 15)

A Proposta Curricular de Santa Catarina (1998) tem como ponto de partida o seguinte pressuposto: O conhecimento acumulado historicamente constitui-se num patrimônio cultural da humanidade e como tal precisa ser socializado. Esta socialização implica a sua garantia a todas as pessoas. O documento deixa claro que a escola não tem condições de promover a socialização das riquezas materiais, porém, no momento em que socializa a riqueza cultural, ela estará abrindo possibilidades de acesso aos bens materiais. Sendo assim, a concepção assumida pelo Estado de Santa Catarina através desse documento é a "concepção histórico-cultural de aprendizagem, também chamada sócio-histórica ou sociointeracionista". (Proposta Curricular do Estado de Santa Catarina, 1998, p. 160)

Para analisar o Contestado nos currículos escolares da educação básica, torna-se indispensável esta visão dos fundamentos epistemológicos que norteiam as políticas educacionais do Estado de Santa Catarina. No entanto, é necessário também destacar aspectos que permeiam a concepção norteadora para o ensino de história, explicitada da seguinte maneira: 
Nesta concepção destaca-se o reconhecimento dos níveis históricos do vivido, do refletido e do concebido. No vivido, encontram-se os homens e suas experiências concretas. Trata-se do tempo imediato que é observado à primeira vista, é a descrição do que se vê sobre o tema. No refletido acontecem as mediações entre o tempo imediato e a memória que constituem as dimensões temporais a serem resgatadas. É o momento regressivo do método, no qual mergulhamos na complexidade vertical das relações sociais. Trata-se de ir às fontes e datar cada elemento da vida material ou social. O nível concebido define-se pelo conhecimento histórico a partir da reconstrução historiográfica dos processos histórico-culturais, ou seja, a partir dos referenciais teóricos do pesquisador, ele procede a análise do problema abordado. (SANTA CATARINA, 1998, p. 161)

O que se propõe através deste documento é que a história trabalhada nas escolas da rede pública estadual vá além daquela visão vertical de ensino, ou seja: datas, fatos, causas e consequências, e que os processos e os fenômenos analisados sejam investigados em diferentes temporalidades. Por isso, a Proposta evidencia que a produção do saber histórico se inicia com o tema que se formula a partir da verificação de um problema. É de grande importância que o professor, enquanto pesquisador, num confronto entre o vivido e o concebido na perspectiva de um novo tempo, trabalhe voltado à solução do problema. A Proposta Curricular do Estado de Santa Catarina deixa claro: "Nesta dimensão, na busca de superar o ensino de História enquanto simples repasse de informações, entendemos que o conhecimento histórico é uma construção de vários sujeitos." (Idem)

\section{O Contestado e a história regional nos currículos da educação básica - Uma visão de professores da Rede Pública}

O movimento social do Contestado e seus desdobramentos na atual situação educacional da região constituem tema de grande amplitude. No momento em que se buscam elementos explicativos para as interrogações sobre o que faz com que hoje sejamos o que realmente somos, torna-se indispensável recorrer às instituições encarregadas da educação formal na sociedade. Ao mesmo tempo em que influem na determinação dos aspectos sociais, políticos e econômicos, estas instituições sofrem determinações. Nesta pesquisa, com o intuito de analisar o espaço ocupado pelo 
Contestado e pela História Regional, foram entrevistados três Professores, que exercem suas atividades profissionais na rede pública estadual em Curitibanos. Para sistematizar as entrevistas com os professores, optou-se pelos seguintes eixos temáticos: a) A importância da História nos currículos escolares; b) O Contestado e a História Regional nos currículos escolares de educação básica; c) o cotidiano do professor de história.

a) A importância da história nos currículos escolares

Por tradição e influência da fragmentação do processo produtivo advinda dos sistemas de produção do mundo capitalista, a escola criou compartimentos para as diferentes áreas de saber. $\mathrm{Na}$ atualidade, embora os inúmeros discursos voltados à globalização do conhecimento, as instituições educacionais ainda mantêm uma matriz curricular dividida em disciplinas. Visualizando esta realidade, questionaram-se os professores sobre a importância da história nos currículos escolares. A professora $\mathrm{n}^{\circ} 1$ primeiramente se referiu à insuficiência do número de aulas, face à carga horária das outras disciplinas e destacou a importância da história no processo de formação do indivíduo. Diante do número reduzido de aulas, faz a seguinte observação: “De quatro aulas de história semanais que tínhamos no passado, pela desvalorização da história, a carga horária semanal foi reduzida para duas horas". A professora $\mathrm{n}^{\circ} 1$ foi questionada: Por parte de quem ocorreu esta desvalorização? Partindo do pressuposto de que no passado a carga horária era de quatro horas semanais, o que levou a esta perda significativa? Sobre esta questão a professora entrevistada deu a seguinte resposta:

Eu acredito que ficou aquela coisa das aulas de história, filosofia e sociologia... aquela coisa meia banal. Houve época que a mesma ficou restrita a decorar fatos e datas, mas que não era trabalhada toda a parte ética e moral. Muitos professores não ministram as aulas de história como elas devem ser trabalhadas. Por causa da desvalorização da história, focalizaram a matemática e o português e tiraram as aulas de história. Na época foi uma briga muito grande.

A professora foi solicitada a explicar quem foi ou quem foram os responsáveis por estas mudanças. A professora entrevistada salientou ser essa uma opção da Secretaria Estadual de Educação, que argumentava na época a necessidade de ser aumentada a carga horária das exatas em detrimento das humanas. Frente a este posicionamento a 
entrevistada foi questionada se não é paradoxal esta opção, diante das concepções que estão na essência da Proposta Curricular do Estado de Santa Catarina. Solicitou-se também que a entrevistada aprofundasse a observação de que existem professores que não trabalham de acordo com essa concepção. A professora fez o seguinte comentário:

Eu acredito que para trabalhar história, você tem que estar focando o diaa-dia do aluno, você tem que estar interagindo, e ele tem que ser um questionador. Ele tem que ser crítico da história. Ele tem que buscar conhecer o fato, entendê-lo e não simplesmente decorar datas. O aluno tem que conhecer na profundidade, questionando as consequências para os nossos dias para que sejam tiradas conclusões a respeito do fato histórico.

A professora $n^{0} 1$ foi solicitada a explicar como é realizado o trabalho dos professores de história que não trabalham dentro desta concepção ou perspectiva. A respeito desta situação a professora esclareceu que eles trabalham seguindo a rígida lógica dos livros didáticos e insistindo na leitura e interpretação por parte dos alunos de seus conteúdos desprovidos de qualquer crítica. Diante desta explicação a entrevistada foi questionada se esta postura pedagógica ainda se faz presente em sala de aula na atualidade, e ela afirmou categoricamente que esta prática ainda faz parte do cotidiano de muitos professores que não têm um compromisso sério com a educação, e enfatizou: “O professor de história não pode ficar sentado e ouvir seus alunos. Nós, enquanto professores, devemos estar questionando e fazendo intervenções em sala de aula, é importante ter bem claros os objetivos". O professor $n^{\circ} 2$, ao ser entrevistado, destacou que faz pouco tempo que trabalha a disciplina de história, mas vê na história o resgate do município, da região e do próprio Brasil. O professor salientou que a história vem contribuir para a integração do aluno na sociedade. "A gente percebe que o pessoal conhece pouco da história local e do Brasil”. Solicitou-se do professor $n^{\circ} 2$ sua opinião a respeito do pouco conhecimento da história regional por parte de nossos alunos. $O$ professor dá a seguinte explicação: "Isto é uma questão de se organizar o currículo, de se organizar o conteúdo. Este teria que ser mais trabalhado nas séries iniciais, uma vez que hoje, no ensino médio, se trabalha mais história geral". O professor entrevistado $n^{\circ} 3$ teceu a seguinte consideração em relação à importância da história no currículo escolar da educação básica:

Eu trabalho com o ensino médio já há oito anos, trabalhei pouco com o ensino fundamental. Com relação à história regional, ela reflete um pouco a questão de material, existe uma certa escassez de material sobre nossa região. Nós somos um povo serrano que sente a necessidade de contar a sua própria história. Nós temos falta de materiais, temos falta de pessoas que pesquisem esta história. Para se trabalhar tem que garimpar 
material. Grande parte do material produzido foi de gente de fora, de Florianópolis.

Na sequência o entrevistado foi questionado a respeito da pouca produção e sobre o princípio da pouca produção existente. O professor $n^{\circ} 3$ mostrou que tudo está muito ligado ao interesse de quem pesquisa, mas grande parte do que é produzido pode ser classificado como superficial, e ele tentou mostrar a pouca preocupação da Universidade em buscar o resgate desta História. O professor deixou claro ainda o seguinte: "A história precisa de profissionais com incentivo político, incentivo ético e incentivo moral... Vivemos uma pobreza de valores". Ele foi questionado sobre a existência de vontade política para o resgate desta história. O professor $n^{\circ} 3$ interpretou esta questão no sentido de que os políticos se preocupam com o que dá retorno eleitoral, sendo que a cultura não proporciona votos: "A cultura não devolve para o político um cargo importante, mais tarde".

b) O Contestado e a história regional nos currículos escolares de educação básica

O processo de educação de um povo encontra-se ligado diretamente à valorização da história regional. Os professores foram inquiridos sobre o Contestado e a história regional nos currículos de educação básica. A professora entrevistada $n^{\circ} 1$ foi questionada sobre o trabalho em sala de aula. A professora mostrou que o Contestado é um conteúdo específico da $7^{\mathrm{a}}$ série do ensino fundamental, sendo que ela trabalha em todas as séries do ensino fundamental e do ensino médio. $\mathrm{Na} 2^{\mathrm{a}}$ e $3^{\mathrm{a}}$ séries do ensino médio o assunto é trabalhado em Estudos Regionais. A professora entrevistada destacou os seguintes aspectos: "Curitibanos foi o grande palco da Guerra do Contestado, a cidade foi incendiada. Nós temos o monumento do Monge João Maria e a história do batismo em águas correntes. A história de Curitibanos não é valorizada”.

A entrevistada foi questionada sobre o que leva à não valorização da história regional e respondeu que uma das principais causas é a falta de empenho no sentido de valorização da cultura local. Nossos monumentos e espaços históricos estão relegados ao desleixo, e ela citou concretamente o Capão da Mortandade e o monumento ao monge João Maria. Questionada sobre o acontecimento mais importante para Curitibanos e região: a Revolução Farroupilha ou a Guerra do Contestado? A professora expressou que, do ponto de vista histórico, Curitibanos tem uma maior relação com o movimento do Contestado, haja vista a Revolução Farroupilha ter uma ligação mais direta com o Rio 
Grande do Sul. Em relação à Revolução Farroupilha, a professora evidenciou que fomos palco apenas de uma batalha no Capão da Mortandade. Porém, destacou que Curitibanos valoriza mais a Revolução Farroupilha, como forma de exibicionismo e não de entendimento histórico desta Revolução. A entrevistada foi interrogada com o objetivo de buscar as possíveis causas de em Curitibanos e região não se valorizar o Contestado. Ela esclareceu: "Pelo sistema coronelista que nós temos, e ainda dizem que mudamos a partir da eleição do último Prefeito. Vivemos num sistema de coronéis que faz a sua leitura da Revolução Farroupilha como marco mais importante da história local”. O professor $\mathrm{n}^{\circ} 3$, quando questionado a respeito do Contestado e da História Regional, falou sobre a pouca divulgação e a falta de incentivo, e conclui: "Nós somos um povo caboclo, e tivemos uma formação cabocla. O caboclo historicamente não se preocupou em divulgar esta história por uma questão cultural”. Perguntado de onde vem esta questão cultural, o professor $n^{\circ} 3$ respondeu: “Nós, assim como os indígenas, até hoje não valorizamos suficientemente nossa cultura". No que se refere a esta categoria, o professor $\mathrm{n}^{\circ} 2$ colocou que o político local deve incentivar o resgate desta história. No sentido provocativo, perguntou-se aos entrevistados se a divulgação do Contestado não mexeria com os mecanismos de poder. Tanto o professor $n^{\circ} 2$ quanto o professor $n^{\circ} 3$ afirmaram que certamente isto aconteceria e de modo especial com os poderes instituídos. O pesquisador mostrou que o objetivo desta pesquisa é analisar o discurso educacional feito no processo de educação deste povo. Tendo em vista esse objetivo, questionou que discurso foi feito na educação deste povo. O professor $n^{\circ} 3$ respondeu: “A Igreja que aqui se estabeleceu e se envolveu no movimento do Contestado, porque era a única instituição cultural que tinha alguma coisa para passar para este povo. As Igrejas encontravam-se ligadas aos coronéis, que mandavam nesta região". O entrevistado foi perguntado se estes ditos coronéis se extinguiram ou ainda estão presentes. Sua resposta foi que eles estão presentes na política. O professor esclareceu ainda que eles se fazem presentes na economia. Questionado sobre esta problemática, o professor $n^{\circ} 2$ fez o seguinte comentário: “Em todos os setores da sociedade estão presentes os coronéis". Diante da afirmativa de que os coronéis se fazem presentes em todos os setores, perguntou-se sobre sua presença na educação. $O$ professor $n^{\circ} 3$ faz a 
seguinte observação: “Na nossa educação temos muitos coronéis... Principalmente porque a educação hoje está envolvida com a política. Os políticos dão o direcionamento". O professor $n^{\circ} 2$ concordou com esta posição e acrescentou: “Existem siglas políticas que fazem com que se cumpram as determinações dos que a comandam. Em todos os setores da sociedade existem coronéis". Partindo deste pressuposto os professores foram interrogados se existe interesse por parte destes grupos dominantes de que a história local e regional seja contada. Os entrevistados responderam que não existe interesse que esta história seja explorada.

O professor $\mathrm{n}^{\circ} 1$ destacou ainda que esta postura deve-se ao fato de que os mandantes locais têm receio de perder a autoridade. Sobre esta questão o professor $n^{\circ} 3$ destacou que os coronéis se fazem presentes nos diversos setores da sociedade, com uma postura altamente centralizadora de poder. O Professor $\mathrm{n}^{\circ} 2$ enfatizou: "Este mandar significa assim, só divulgo o que é de nosso interesse. A própria história do Contestado e não somente a história do Contestado, o povo sabe o que deve saber". A professora $\mathrm{n}^{0} 1$ destacou que a cidade é monitorada pelos coronéis e explica que este sistema sobrevive ainda no momento histórico atual. Ela explicou:

Nós ainda continuamos sendo dominados pelo sistema de coronéis. Os coronéis hoje estão atualizados, civilizados... Até é um termo que os alunos disseram: vivemos num sistema de coronéis civilizados. É um mandar por trás da cortina. Os que pertencem a este grupo se preocupam na manutenção deste sistema de poder. Os que não fazem parte acham que tem que existir mudanças, mas não sabem como operacionalizá-las.

Novamente se perguntou: Onde estão estes coronéis? A professora $n^{\circ} 1$ deu a seguinte explicação: “Estes coronéis, hoje, estão dentro da Prefeitura, são os mandantes de nosso comércio, são os que têm maior poder aquisitivo e que determinam quem entra e quem sai, quem pode e quem não pode". Outra pergunta feita à professora $n^{\circ} 1$ foi se existem coronéis na educação. A entrevistada afirmou que eles encontram-se presentes nos diversos setores da Sociedade. Uma outra arguição foi lançada no sentido de aprofundar a temática do coronelismo e sua relação com o processo de educação da população, através da seguinte pergunta feita à professora $n^{\circ} 1$ : Existe relação entre 0 coronelismo e a educação social de nosso povo? O termo educação social refere-se aos 
mecanismos institucionais no processo de educação da população. A entrevistada assumiu o seguinte posicionamento:

Eu acho forte demais porque nós não podemos ser o que nós somos. Não podemos mostrar muito o que somos, não podemos mostrar muito o que pensamos. Não podemos mostrar às claras o que realmente queremos porque dentro da educação é pior ainda, e você acaba sendo perseguido. Então você não pode expor o que pensa, ou seja, você pode expor até o momento que aquilo é bom. A classe pobre pode se expressar até determinados limites. A maior parte das classes mais abastadas faz o discurso do poder. A lógica aqui instaurada encontra-se em fazer o que os detentores do poder querem.

Diante do exposto a professora foi interrogada sobre a cultura do silêncio imposta às classes menos abastadas. Ela fez o seguinte esclarecimento: “Com certeza são poucos os que conseguem colocar o que realmente sentem e quando colocam vêm represálias. $O$ medo de represálias é que faz com que eles aceitem tudo como está". A professora concluiu a entrevista com estas palavras: "Nesta entrevista eu realmente desabafei..."

c) O cotidiano do professor de história - suas práticas ou angústias.

Nesta parte se pretende analisar a prática docente dos professores de história, suas angústias, dificuldades e avanços. Inicialmente os três professores entrevistados mostraram que uma das grandes dificuldades para se trabalhar o Contestado, bem como a História Regional, reside na falta de material didático adequado. Este posicionamento dos três professores relacionado aos materiais didáticos reside no fato de não se ter um professor pesquisador, à carga horária talvez excessiva de trabalho efetivo e às salas de aula superlotadas de alunos. A professora $\mathrm{n}^{\circ} 1$ mostrou que tem um trabalho de Estudos Regionais. Esta disciplina trata da história de Santa Catarina, sendo que o Contestado faz parte de um dos conteúdos selecionados para serem ministrados. A professora $n^{\circ} 1$ falou que é trabalho do terceiro para o quarto bimestre, na $3^{\text {a }}$ série do ensino médio. Considerando que esta cadeira tem uma carga de 01 aula semanal na matriz curricular, num bimestre de estudos o aluno tem aproximadamente 10 horas/aula, o que é uma carga horária reduzidíssima para se explorar este conteúdo programático. Outro aspecto destacado pela professora $n^{\circ} 1$ está relacionado a como o Contestado é visto no currículo escolar. Ela respondeu: “O tema Contestado só é falado mesmo por nós, professores de 
história". Outra questão formulada à entrevistada foi no sentido saber como a escola

valoriza temas relacionados ao Contestado e à História local. A professora $\mathrm{n}^{\circ} 1$ emitiu o seguinte parecer:

Eu vejo assim que a maioria dos professores não estão preocupados com o que está acontecendo ao redor, com o que está acontecendo aqui em nossa cidade. Os professores de modo geral estão preocupados com o seu cotidiano, com o seu umbigo.

A professora ressaltou que não existe valorização da história local por parte da maioria dos professores. Grande número destes dão pouca importância a este conteúdo. Perguntada sobre o apoio dado pela direção da escola, a professora enfatizou que esta a apoia em projetos que ela realiza com os alunos. Entretanto, perguntou-se à professora $\mathrm{n}^{0} 1$ se a direção tinha iniciativa de projetos relacionados a estes conteúdos, numa perspectiva interdisciplinar ou multidisciplinar. A entrevistada deixou transparecer que, no início do ano letivo, sem qualquer direcionamento, de forma espontaneísta, os projetos surgem por iniciativa dos professores, sem qualquer relação com o projeto educativo da escola. E a professora esclareceu que a direção assim se posiciona: "Eles dizem: Se nós não estivermos ligados diretamente a isto, nós estamos aqui para apoiar”. Perguntou-se a ela se existe algum projeto de cunho pedagógico de iniciativa da direção da escola sobre o Contestado ou sobre temas relativos à História Regional. A professora esclareceu que projetos voltados a estes conteúdos são de iniciativa dos professores e nunca da direção, e concluiu fazendo a seguinte observação: “Eles nos dão liberdade para ver o projeto que queremos fazer, por isso que agora a gente enfoca". A professora $n^{\circ} 1$ expôs que seu trabalho em sala de aula é feito através de muita reflexão e de projetos. Uma das questões levantadas foi sobre as dificuldades que o professor de história enfrenta no cotidiano da sala de aula. A professora esclareceu os seguintes pontos: Nos projetos desenvolvidos existe a não participação de colegas de outras áreas de ensino. Quanto à história local e regional, há falta de livros didáticos e a própria desvalorização dos poderes municipais. Dentre os motivos da não participação a docente apontou a questão cultural e a centralização do poder. Os professores foram questionados a respeito da concepção de história a ser trabalhada. O professor 3 deu a seguinte resposta: 
Eu acho que uma história que procure a valorização do local e do regional, do povo daqui, do resgate da sua história e dos seus valores. Uma vez que resgatar a história é resgatar o seu próprio valor. É tudo isto que constitui o ser humano. Nós somos reflexo desta história e nós só temos um valor cultural a partir do momento em que nós falamos com o nosso passado. É o nosso jeito de ser.

Já o professor $n^{\circ} 2$ destacou a centralização de poder na região em que os mecanismos são controlados por coronéis que mandam. "Este mandar significa assim, eu só divulgo o que é do 'nosso' interesse. O povo sabe somente o que deve saber”. $\mathrm{Na}$ sequência, os professores foram questionados a respeito da maneira como trabalham a história, se existe espaço para o trabalho do tema Contestado e se este tema é uma preocupação central da escola ou é apenas apresentado de forma fragmentada. Os professores disseram que ele é apresentado de forma fragmentada sendo evidenciado somente em alguns momentos ou em alguns projetos. O professor $n^{\circ} 2$ falou da inexistência de projetos, evidenciando a necessidade de que venham da Secretaria Estadual de Educação. O professor disse que trabalha com a $1^{\text {a }}$ série do ensino médio e que, nos seus planos, bem como na sua prática em sala de aula, não há espaço para trabalhar a História Regional. Mencionou também a falta de material didático para o desempenho das atividades docentes nesta área. O professor $n^{\circ} 3$ assumiu o mesmo posicionamento do professor $n^{\circ} 2$ quanto ao material de pesquisa para se trabalhar no cotidiano escolar, e fez o seguinte comentário:

A História Geral não abre espaço, por uma questão até de tempo, ou seja, carga horária semanal. Você não consegue trabalhar com duas aulas por semana, nem sequer a História Geral e do Brasil de forma adequada. Você tem que encontrar um meio de passar para o aluno aquilo que você enquanto profissional vai dizer e o próprio material que a escola passa para você. Nestas poucas aulas você fica completamente limitado no sentido de tentar buscar mais recursos para que a aula se torne melhor. Infelizmente nós temos dificuldades, os conteúdos vêm da editora.

Os professores $n^{\circ} 2$ e $n^{\circ} 3$ falaram que trabalham com apostila, sendo que 0 conteúdo a ser trabalhado já vem determinado e o Contestado não se encontra na apostila. O professor $n^{\circ} 2$ destacou: “Caso não se cumpra a apostila ou o livro didático, vem a crítica do aluno. O conteúdo é bastante restrito. A nossa sociedade está se preocupando com a questão financeira e não se preocupa se o aluno está aprendendo ou não". Os professores foram perguntados a respeito das dificuldades em ser profissional 
de história hoje e se a escola valoriza a história. O professor $n^{\circ} 2$ disse que a área de humanas é muito desvalorizada. O professor $n^{\circ} 3$ fez a seguinte declaração: “Os militares desvalorizaram as ciências humanas e por consequência a história". O professor entrevistado concluiu que a matemática, a física, a química e a língua portuguesa se tornaram mais importantes, pelo menos no ensino fundamental e médio. Entretanto, o professor $n^{\circ} 2$ salientou que, além da falta de material, existe a falta de interesse do aluno e a superlotação das salas de aula... O referido professor concluiu: “Muito conteúdo envolvendo pouca prática. As aulas ministradas são muito expositivas e os alunos não demonstram interesse pela parte histórica, tanto local como regional”.

As entrevistas e os questionários aplicados junto aos acadêmicos calouros, matriculados na $1^{\text {a }}$ fase dos cursos de graduação da Universidade do Contestado-Campus de Curitibanos, mostraram que a formação sócio-histórica proporcionada ao longo da educação básica carece de uma revisão. Os acadêmicos deixaram claro que, no processo de formação, Ihes foi passada uma história calcada nos pressupostos positivistas, fragmentada, que enaltece heróis, esquecendo-se do ser humano sujeito de sua própria história. Os acadêmicos calouros têm uma visão bastante simplista da história regional, desprovida do espírito de investigação científica e, por que não dizer, calcada no senso comum. É interessante salientar que, após vinte anos de luta, estudos e projetos, a Proposta Curricular de Santa Catarina ainda não se encontra incorporada à pratica da maioria dos docentes.

Quanto às entrevistas realizadas com os professores, pode-se observar uma desvalorização das Ciências humanas e a realização de projetos isolados dentro das escolas, o que faz concluir que há uma falta de articulação, no cotidiano escolar, com o projeto educativo. A carga horária da disciplina de história é reduzidíssima e os trabalhos nas escolas são fragmentados, estando-se longe de uma ação de coletividade pedagógica, ou seja, de um trabalho em equipe. Frente à sobrecarga de trabalho e à opção administrativa das instituições escolares, muitos trabalhos encontram-se engessados, circunscrevendo-se ao livro didático ou à apostila por parte dos professores.

O movimento social do Contestado e seus desdobramentos na atual situação educacional da região constituem tema de grande amplitude. No momento em que se 
buscam elementos explicativos para as interrogações sobre o que faz com que hoje sejamos o que realmente somos, torna-se indispensável recorrer às instituições encarregadas da educação formal na sociedade. Ao mesmo tempo em que influem na determinação dos aspectos sociais, políticos e econômicos, estas instituições sofrem determinações.

\section{Considerações finais}

O movimento social do Contestado aconteceu dentro de um contexto marcado pela dominação. A educação instituída pelos dominantes se perpetuou através de gerações, influindo decisivamente na educação do povo desta região. O que se observa neste projeto são ações centralizadoras, marco de uma educação repressora que se reproduz até os nossos dias. Nesse ambiente os dominados são massificados, o terror branco é utilizado como arma geradora da cultura do medo e do silêncio. Esta prática anula o poder de criação do homem do Contestado, estimulando a apatia e a submissão, satisfazendo os interesses dos dominantes. Os excluídos são vítimas desse projeto. Para não despertá-los a buscar seus direitos, impõe-se aos que educam torná-los passivos e domesticados. Por outro lado, perpetua-se a cultura da satisfação entre os bemsucedidos, os vencedores.

Acredita-se que, para sair dessa situação, para a formação de cidadãos ativos, é imprescindível uma educação sócio-política, capaz de fazer com que o ser humano supere a apatia e o despreparo e se volte para participação, o pluralismo e a democracia, fundamentais para o desenvolvimento humano.

Outro aspecto importante na formação do indivíduo para a cidadania é a preservação da memória histórica de um povo, como forma de se vivenciar, no cotidiano, o preservar de certas informações passadas, destacando-as como importantes para o momento presente. Nessa perspectiva, o movimento social do Contestado é fortemente marcado pela oralidade, e de certa forma influenciado pela reprodução da história oficial. Neste contexto, do passado ao momento presente, preservam-se na memória coletiva as abordagens míticas e o culto às famílias tradicionais. O povo, o sertanejo, o homem 
sofrido do sertão, não faz parte desta história, uma vez que foi deixado de lado pela história oficial.

A Região, bem como o Estado de Santa Catarina, não fugindo à regra, também tem a sua história oficial. O que se questiona são determinados aspectos que têm uma ligação direta com a educação instituída na região e no estado. A história instituída foi produzida seguindo os pressupostos de uma historiografia positivista a serviço da manutenção do status quo. Esta concepção de história é vista de forma dogmática, como a verdadeira história, e com isto se limita o espaço para discussão de questões de fundamental importância quando se quer traçar um projeto de desenvolvimento. Questões sociais e econômicas que são verdadeiras feridas tornam-se camufladas e passam até por um processo de naturalização.

No que se refere à presença do tema do Contestado nos currículos escolares, observou-se que estes, de forma velada, assumem uma certa aparência de neutralidade. Porém, como não existe neutralidade em educação, torna-se bastante palpável que servem aos interesses dos grupos dominantes da região. As escolas da rede pública, ainda na atualidade, sofrem ingerência político-partidária, o que provoca um esfacelamento do processo, bem como do trabalho docente. Percebe-se claramente que as políticas educacionais emanam de cima para baixo, sendo o professor reduzido a mero executor, não mais àquele que concebe o processo.

A educação na região do Contestado e no Estado de Santa Catarina ainda carece de ir ao encontro da sociedade, uma vez que o projeto implementado carrega elementos de uma violência simbólica a serviço dos dominantes, assumidos pelas instituições educacionais atreladas ao sistema. Existe forte influência do setor produtivo nos currículos escolares. O questionável é saber dentro de qual lógica o econômico influi no setor educacional. Pelo que se observa, a fragmentação ocorrida no setor produtivo veio fazer parte do educacional nas salas de aulas. Ressalta-se que o currículo oculto passou a privilegiar as habilidades relativas à obediência e à subserviência às autoridades. Cabe, portanto, buscar espaços para que a História Regional seja valorizada como um dos componentes do currículo de educação básica do Estado de Santa Catarina. 


\section{Referências}

APPLE, Michael W. Educação e poder. Tradução: Maria Cristina Monteiro. Porto Alegre: Artes Médicas, 1989.

CASTELS, et al. Novas Perspectivas críticas em educação. Porto Alegre: Artes Médicas, 1996.

D’ASSUMPÇÃO, Herculano Teixeira. A campanha do Contestado. Bello Horizonte: Imprensa Official do Estado de Minas Geraes, 1917.

FREI BETTO. Batismo de sangue. São Paulo: Casa Amarela, 2000.

FRIGOTTO, Gaudêncio. A educação e a crise do capitalismo real. São Paulo: Cortez, 2000.

GIROUX, Henri. Cruzando as fronteiras do discurso educacional. Porto Alegre: Artmed, 1999.

KARL, Marx; ENGELS Friederich . A ideologia Alemão. São Paulo Hucitec, 1986.

LEMOS, Zélia de Andrade. Curitibanos na História do Contestado. Curitibanos: Impressora Frei Rogério, 1983.

MOREIRA, Antônio Flávio; SILVA, Tomaz Tadeu (orgs.). Currículo, Cultura e sociedade. São Paulo: Cortez, 2002.

SACHWEH, Maria da Salete. Educação, dominação e libertação na guerra Santa do Contestado. Florianópolis: Impensa Oficial do Estado de Santa Catarina, 2002.

SACRISTÁN, Gimeno J.; GÓMEZ, A. I. Pérez. Compreender e transformar o ensino. Tradução. Ernani F. da Fonseca Rosa. Porto Alegre: Artes Médicas, 1998.

SANTA CATARINA. Secretaria de Estado da Educação e do Desporto. Proposta Curricular do Estado de Santa Catarina. Educação Infantil, Ensino Fundamental e Ensino Médio. Florianópolis: Imprensa Oficial do Estado de Santa Catarina, 1998.

SANTOMÉ, Jurjo Torres. Globalização e Interdisciplinaridade. Tradução: Cláudia Schilling. Porto Alegre: Artmed, 1998. 
ROCHA, Ubiratã. História do Currículo e cotidiano escolar. São Paulo: Cortez, 2002

THOMÉ, Nilson. Primeira História da educação escolar na região do Contestado. Caçador:

Universidade do Contestado, 2002.

Recebido em: 04/07/2012 Aprovado em: 08/04/2013

Universidade do Estado de Santa Catarina - UDESC Centro de Ciências Humanas e da Educação - FAED

Revista PerCursos

Volume 14 - Número 26 - Ano 2013 revistapercursos@gmail.com 